Vol. 6 (1997): 283-294.

\title{
Effects of composite casein and $\beta$-lactoglobulin genotypes on renneting properties and composition of bovine milk by assuming an animal model
}

\author{
Tiina Ikonen, Matti Ojala \\ Department of Animal Science, PO Box 28, FIN-00014 University of Helsinki, Finland, \\ e-mail: tiina.ikonen@helsinki.fi \\ Eeva-Liisa Syväoja \\ Valio Ltd., Research and Development Centre, PO Box 390, FIN-00101 Helsinki, Finland
}

\begin{abstract}
The effects of $\kappa-\beta$-casein genotypes and $\beta$-lactoglobulin genotypes on the renneting properties and composition of milk were estimated for 174 and 155 milk samples of 59 Finnish Ayrshire and 55 Finnish Friesian cows, respectively. As well as the random additive genetic and permanent environmental effects of a cow, the model included the fixed effects for parity, lactation stage, season, $\kappa-\beta$ casein genotypes and $\beta$-lactoglobulin genotypes. Favourable renneting properties were associated with $\kappa-\beta$-casein genotypes $A B A_{1} A_{2}, A B A_{1} A_{1}$ and $A A A_{1} A_{2}$ in the Finnish Ayrshire, and with $A B A_{2} B$, $\mathrm{AAA}_{1} \mathrm{~A}_{3}, \mathrm{AAA}_{2} \mathrm{~A}_{3}, \mathrm{ABA}_{1} \mathrm{~A}_{2}$ and $A \mathrm{AA}_{2} \mathrm{~A}_{2}$ in the Finnish Friesian. The favourable effect of these genotypes on curd firming time and on firmness of the curd was partly due to their association with a high $\mathrm{K}$-casein concentration in the milk. The effect of the $\kappa$-casein $\mathrm{E}$ allele on renneting properties was unfavourable compared with that of the K-casein B allele, and possibly with that of the A allele. The $\beta$-lactoglobulin genotypes had no effect on renneting properties but they had a clear effect on the protein composition of milk. The $\beta$-lactoglobulin AA genotype was associated with a high whey protein $\%$ and $\beta$-lactoglobulin concentration and the BB genotype with a high casein $\%$ and casein number.
\end{abstract}

Key words: coagulation properties, milk protein polymorphism

\section{Introduction}

Several studies have discussed the environmental and genetic factors that influence milk renneting properties. A number of workers have reported the favourable effect of the K-casein B allele on renneting properties (e.g., Schaar 1984, Aaltonen and Antila 1987, Pagnacco and Caroli
1987). There is therefore interest in using $\mathrm{K}$-casein genotypes as a selection criterion when breeding for more favourable renneting properties and, thereby, better use of milk in cheese production. Conflicting results have been obtained for the effects of genotypes of $\alpha_{\mathrm{s} 1}{ }^{-}$and $\beta$ caseins and $\beta$-lactoglobulin on renneting properties. The origin, size and structure of the data, milk protein genotype frequencies, statistical 


\section{AGRICULTURAL AND FOOD SCIENCE IN FINLAND}

Ikonen, T. et al. Renneting properties and composition of bovine milk

methods and models used or linkage disequilibrium between the casein loci may explain some of the discrepancies.

The effects of milk protein genotypes on renneting properties have been estimated by a least squares method (e.g., Tervala et al. 1985, Pagnacco and Caroli 1987, Davoli et al. 1990, Macheboeuf et al. 1993). When used for estimating single-gene effects on quantitative traits, this method ignores some or all of the polygenic effects (Kennedy et al. 1992). Because of probable confounding between single-gene effects and polygenic effects, it is thus possible to find an excess of spurious significant effects of the single genes. Kennedy et al. (1992) showed that the use of mixed model procedures under an animal model treating single-gene effects as fixed effects can provide unbiased estimates of singlegene effects and exact tests of associated hypotheses for pedigreed populations.

Various models have been applied for estimating milk protein genotype effects. A few studies have estimated the effect of genotypes of one protein at a time (Schaar 1984, Schaar et al. 1985, Davoli et al. 1990, Machboeuf et al. 1993). Others have included the genotypes of some or all major milk proteins in a model simultaneously (Feagan et al. 1972, Pagnacco and Caroli 1987, Tervala et al. 1985, Oloffs et al. 1992). Only a few authors have estimated the effects of composite genotypes of some or all major milk proteins (El-Negoumy 1972, Pagnacco and Caroli 1987). Because the casein loci are tightly linked (e.g., Grosclaude et al. 1973, Threadgill and Womack 1990), the genotype effect of a casein locus may not be independent of the genotype effect of another locus. It seems therefore reasonable to estimate casein genotype effects simultaneously by using combined genotypes (Ojala et al. 1997).

In this study we estimated the effects of composite $\kappa$ - $\beta$-casein genotypes and $\beta$-lactoglobulin genotypes on the renneting properties and composition of bovine milk by assuming an animal model. We also studied the associations of renneting properties with the composition of milk.

\section{Material and methods}

\section{Milk samples}

A total of 59 Finnish Ayrshire (FAy) cows from Helsinki University's experimental herd Viikki and 55 Finnish Friesian (FFr) cows from the experimental herd Suitia were genotyped for $\alpha_{\mathrm{s1}}{ }^{-}$, $\beta$ - and $\kappa$-caseins and $\beta$-lactoglobulin by isoelectric focusing in polyacrylamide gels (Erhardt 1989). The FAy cows were born between 1980 and 1989, and the FFr cows between 1982 and 1989.

The effects of milk protein genotypes on the renneting properties and composition of milk were estimated by sampling the cows three times during lactation: 1, 3 and 5 months after calving. The cows calved from July 1990 to June 1991, and the sampling period lasted from the end of September 1990 to the end of October 1991. When the cows were housed indoors, the average proportion of concentrates in the feed, as determined on energy bases, was $37 \%$ for the FAy and $42 \%$ for the FFr. In 1991, the FAy cows were on pasture from the end of May to the end of September, and the FFr cows from mid-June to the end of September.

Because the cows were at different stages of lactation during sampling, the number of samples per cow varied from two to three, but for most cows it was three. The total number of milk samples was 174 for the FAy and 155 for the FFr. The milk samples (evening + morning milkings) were analysed for the following characteristics: daily milk yield, renneting properties, gross composition and protein composition.

\section{Milk renneting properties}

The renneting properties of individual milk samples $(10 \mathrm{ml})$ determined by a Formagraph (Foss Electric, Hillerød, DK-3400, Denmark) at $32{ }^{\circ} \mathrm{C}$ for $30 \mathrm{~min}$ with $0.20 \mathrm{ml}$ rennet (Renco) liquid diluted in $0.07 \mathrm{M}$ sodium acetate buffer (1:100) were: renneting time $(\mathrm{R})$, curd firming time $\left(\mathrm{K}_{20}\right)$ 


\section{AGRICULTURAL AND FOOD SCIENCE IN FINLAND}

Vol. 6 (1997): 283-294.

and firmness of the curd $\left(\mathrm{E}_{30}\right)$. R was the time from the addition of rennet to milk to the beginning of coagulation. $\mathrm{K}_{20}$ was the time from the beginning of coagulation to the moment the width of the curve was $20 \mathrm{~mm}$. $\mathrm{E}_{30}$ was the width of the curve $30 \mathrm{~min}$ after the addition of rennet. Because milk samples were allowed to coagulate for only $30 \mathrm{~min}$, renneting or curd firming times, or both, were not achieved for some samples owing to poor coagulation. Because the samples that did not coagulate in $30 \mathrm{~min}$ (nine samples from six FAy cows) were divided more or less equally among the milk protein genotypes, these samples were omitted from the statistical analyses of renneting properties.

\section{Composition of milk}

The fat and protein percentages were determined with a Milko-Scan 605 (Foss Electric) and the somatic cell count was made with a Fossomatic cell counter. Because the frequency distribution for the somatic cell count was far from normal in both breeds, the somatic cell counts were logarithmically transformed. $\mathrm{pH}$ was also measured.

The protein composition values determined were: casein and whey protein percentages, nonprotein nitrogen $(\mathrm{mg} / \mathrm{g})$, casein number and the concentrations of $\alpha_{\mathrm{s} 1}{ }^{-}, \alpha_{\mathrm{s} 2}-, \beta$ - and $\kappa$-caseins, $\alpha$ lactalbumin and $\beta$-lactoglobulin $(\mathrm{g} / \mathrm{l})$ in milk. The casein and whey protein percentages and non-protein nitrogen were determined according to International Dairy Federation (IDF) standards (1979 and 1986). Casein number was the proportion of casein in total protein. Concentrations of individual caseins in milk were obtained by multiplying proportions of individual caseins in total casein by casein content. The proportions of individual caseins were determined by fast protein liquid chromatography (FPLC) (Pharmacia Biotech, Uppsala, Sweden) as described by Syväoja (1992). Individual whey proteins were fractionated by FPLC gel filtration on a Superdex 75 HR 10/30 column (Pharmacia Biotech) as described by Syväoja and Korhonen (1994).

\section{Statistical analyses}

The effects of parity, lactation stage, season, $\kappa$ $\beta$-casein $(\kappa-\beta-C N)$ genotypes and $\beta$-lactoglobulin $(\beta-\mathrm{LG})$ genotypes on the renneting properties and composition of milk were estimated using an animal model. Owing to the difference in $\kappa-\beta-C N$ genotypes formed in the FAy and FFr, the records from the two breeds, and thus from the two herds, were analysed separately. The following linear model was assumed:

Model 1:

$\begin{aligned} \mathrm{y}_{\mathrm{ijk} \text { kmno }}= & \mu+\text { parity }_{\mathrm{i}}+\text { lstage }_{\mathrm{j}}+\text { season }_{\mathrm{k}}+\text { casge }_{\mathrm{i}} \\ & + \text { lactge }_{\mathrm{m}}+\mathrm{a}_{\mathrm{n}}+\mathrm{p}_{\mathrm{n}}+\varepsilon_{\mathrm{ijklmno}},\end{aligned}$ where

$\mathrm{y}_{\mathrm{ijklmno}}=$ the $\mathrm{o}_{\mathrm{th}}$ observation of a milk renneting trait or a milk composition variable of the $\mathrm{n}_{\text {th }}$ cow

$\mu \quad=$ general mean

parity $y_{i}=$ fixed effect of the $i_{\text {th }}$ parity class

lstage $_{\mathrm{j}}=$ fixed effect of the $\mathrm{j}_{\mathrm{th}}$ lactation stage class

season $_{\mathrm{k}}=$ fixed effect of the $\mathrm{k}_{\mathrm{th}}$ season class

casge $_{1}=$ fixed effect of the $1_{\text {th }} \kappa-\beta-C N$ genotype class

lactge $_{m}=$ fixed effect of the $m_{\text {th }} \beta$-LG genotype class

$\mathrm{a}_{\mathrm{n}} \quad=$ random additive genetic effect of the $\mathrm{n}_{\mathrm{th}} \operatorname{cow},\left(\mathbf{0}, \mathbf{A} \sigma_{\mathrm{a}}^{2}\right)$

$\mathrm{p}_{\mathrm{n}} \quad=$ random permanent environmental effect of the $\mathrm{n}_{\text {th }} \operatorname{cow},\left(\mathbf{0}, \mathbf{I} \boldsymbol{\sigma}_{\text {pe }}^{2}\right)$

$\mathrm{e}_{\mathrm{ijklmno}}=$ random residual effect, $\mathrm{N}\left(\boldsymbol{0}, \mathbf{I} \boldsymbol{\sigma}_{\varepsilon}^{2}\right)$

Parity was grouped into three classes: first, second and third to ninth lactation; lactation stage into three classes: 1,3 and 5 months after calving; and season into four classes: Sep to Nov, Dec to Feb, Mar to May and Jun to Aug. The classification of $\kappa-\beta-\mathrm{CN}$ and $\beta-\mathrm{LG}$ genotypes is presented in Table 1. Because the FAy was monomorphic for $\alpha_{\mathrm{s1}}$-casein and there were a few cows with the $\alpha_{\mathrm{s1}}$-casein $\mathrm{C}$ allele in the FFr, $\alpha_{\mathrm{s1}}{ }^{-}$ casein genotypes were not considered in the formation of composite genotypes.

The 59 FAy cows with records were daughters of 25 sires and the $55 \mathrm{FFr}$ cows daughters of 32 sires. The number of daughters per sire ranged 
Ikonen, T. et al. Renneting properties and composition of bovine milk

from one to six in the FAy and from one to four in the FFr. Ten FAy sires and 16 FFr sires had only one daughter each. The pedigrees of the cows with records were known for at least two generations, and the total number of animals in the statistical analyses was 352 for the FAy and 568 for the FFr.

In subsequent analyses, the associations of renneting properties with the composition variables of milk were estimated using Model 2, in which one milk composition variable at a time was included as a covariate in Model 1. Otherwise Model 2 worked like Model 1.

Variance components for the random effects $\left(\sigma_{\mathrm{a}}^{2}, \sigma_{\mathrm{pe}}^{2}\right.$ and $\left.\sigma_{\varepsilon}^{2}\right)$ in Models 1 and 2 were estimated from the data sets with the REML VCE package (Groeneveld 1993). The effects of parity, lactation stage, season, $\kappa-\beta-\mathrm{CN}$ genotypes and $\beta$-LG genotypes on various characteristics were tested with the PEST program of Groeneveld (1990). The hypothesis tested was $K^{\prime} b=0$, in which $K^{\prime} b$ contained the maximum number of independent estimable contrasts between classes of a fixed factor in the model. The statistical significance of regression coefficients (Model 2) was obtained by calculating $\mathrm{F}$ values using the difference between $\sigma_{\varepsilon}^{2}$ from Model 1 without a covariate and $\sigma_{\varepsilon}^{2}$ from Model 2 with a covariate. However, no consideration was made about the effect due to the number of independent tests generated by several traits within two different populations.

\section{Results}

\section{Frequencies of $\kappa-\beta-\mathrm{CN}$ and $\beta$-LG genotypes}

The expected number of all possible combinations of $\kappa$ - and $\beta$-casein genotypes was 15 in the FAy and 18 in the FFr. Owing to the small size

Table 1. Number of cows and observations for the composite $\kappa$ - $\beta$-casein genotypes and $\beta$-lactoglobulin genotypes.

\begin{tabular}{|c|c|c|c|c|c|c|}
\hline & \multicolumn{3}{|c|}{ Finnish Ayrshire } & \multicolumn{3}{|c|}{ Finnish Friesian } \\
\hline & $\begin{array}{l}\text { No. of } \\
\text { cows }\end{array}$ & $\begin{array}{c}\text { Percentage } \\
\text { of cows }\end{array}$ & $\begin{array}{l}\text { No. of } \\
\text { obs. }\end{array}$ & $\begin{array}{l}\text { No. of } \\
\text { cows }\end{array}$ & $\begin{array}{c}\text { Percentage } \\
\text { of cows }\end{array}$ & $\begin{array}{l}\text { No. of } \\
\text { obs. }\end{array}$ \\
\hline \multicolumn{7}{|l|}{$\kappa$ - $\beta$-casein } \\
\hline $\mathrm{AAA}_{1} \mathrm{~A}_{1}$ & 2 & 3.0 & 6 & & & \\
\hline $\mathrm{AAA}_{1} \mathrm{~A}_{2}$ & 7 & 12.0 & 21 & 10 & 18.0 & 29 \\
\hline $\mathrm{AAA}_{2} \mathrm{~A}_{2}$ & 14 & 24.0 & 40 & 21 & 38.0 & 60 \\
\hline $\mathrm{AAA}_{123}^{i}$ & & & & 2 & 4.0 & 4 \\
\hline $\mathrm{ABA}_{1} \mathrm{~A}_{1}$ & 2 & 3.0 & 6 & 1 & 2.0 & 3 \\
\hline $\mathrm{ABA}_{1} \mathrm{~A}_{2}$ & 8 & 14.0 & 24 & 8 & 15.0 & 23 \\
\hline $\mathrm{ABA}_{2} \mathrm{~A}_{2}$ & 2 & 3.0 & 6 & 4 & 7.0 & 11 \\
\hline $\mathrm{ABA}=$ & & & & 2 & 4.0 & 5 \\
\hline $\mathrm{AEA}_{1} \mathrm{~A}_{1}$ & 3 & 5.0 & 9 & 4 & 7.0 & 11 \\
\hline $\mathrm{AEA}_{1} \mathrm{~A}_{2}$ & 13 & 22.0 & 38 & 3 & 5.0 & 9 \\
\hline $\mathrm{AEA}_{2} \mathrm{~A}_{2}$ & 2 & 3.0 & 6 & & & \\
\hline $\mathrm{BEA} \mathrm{A}_{1}$ & 2 & 3.0 & 6 & & & \\
\hline $\begin{array}{l}\mathrm{EEA}_{1} \mathrm{~A}_{1} \\
\beta-\lg \end{array}$ & 4 & 7.0 & 12 & & & \\
\hline $\mathrm{AA}$ & 5 & 9.0 & 15 & 7 & 13.0 & 20 \\
\hline $\mathrm{AB}$ & 28 & 47.0 & 82 & 34 & 62.0 & 97 \\
\hline BB & 26 & 44.0 & 77 & 14 & 25.0 & 38 \\
\hline
\end{tabular}

${ }^{\prime} \mathrm{AAA}_{123}=\mathrm{AAA}_{1} \mathrm{~A}_{3}+\mathrm{AAA}_{2} \mathrm{~A}_{3}$

$\beta$-lg $=\beta$-lactoglobulin 
Vol. 6 (1997): 283-294.

of the data sets and linkage disequilibrium in the casein loci, the observed number of combinations was 11 in the FAy and 9 in the FFr (Table 1). The most common $\kappa-\beta-C N$ genotypes were $\mathrm{AAA}_{2} \mathrm{~A}_{2}$ and $A E A_{1} \mathrm{~A}_{2}$ in the FAy, and $\mathrm{AAA}_{2} \mathrm{~A}_{2}$ and $\mathrm{AAA}_{1} \mathrm{~A}_{2}$ in the FFr. Consequently, $46 \%$ of the FAy cows and $56 \%$ of the FFr cows had one of the two most common $\kappa-\beta-C N$ genotypes. The rarest $\kappa-\beta-C N$ genotypes were carried by only one or two cows. The $\beta$-LG AB and BB genotypes were almost equally frequent in the FAy whereas $A B$ was most frequent in the FFr. The $\beta$-LG AA genotype was rather rare in both breeds.

\section{Means and Variation}

\section{Renneting properties}

The average renneting and curd firming times were longer and the firmness of the curd was poorer for milk of the FAy than for milk of the FFr (Table 2). There was considerable variation in renneting properties in both breeds. The coefficients of variation for renneting and curd firming times would have been even larger had the poorly coagulating milk samples reached their extremely long renneting or curd firming times, or both.

Table 2. Milk renneting traits, daily milk yield, and gross and protein composition of milk.

\begin{tabular}{|c|c|c|c|c|c|c|}
\hline & \multicolumn{3}{|c|}{ Finnish Ayrshire } & \multicolumn{3}{|c|}{ Finnish Friesian } \\
\hline & $\bar{x}$ & s.d. & $\mathrm{cv}$ & $\bar{x}$ & s.d. & $\mathrm{cv}$ \\
\hline \multicolumn{7}{|l|}{ Milk renneting } \\
\hline $\mathrm{R}, \min$ & 12.4 & 4.9 & 40 & 11.3 & 3.6 & 33 \\
\hline $\mathrm{K}_{20}, \min$ & 8.1 & 3.3 & 41 & 7.4 & 3.5 & 47 \\
\hline $\mathrm{E}_{30}, \mathrm{~mm}$ & 25.8 & 12.5 & 48 & 31.2 & 10.1 & 33 \\
\hline $\mathrm{E}_{30}^{\prime}, \mathrm{mm}$ & 27.2 & 11.2 & 41 & & & \\
\hline \multicolumn{7}{|l|}{ Milk yield and composition } \\
\hline Daily milk yield, kg & 26.2 & 5.7 & 21 & 26.0 & 6.0 & 23 \\
\hline Fat $\%$ & 4.51 & 0.66 & 15 & 4.27 & 0.69 & 16 \\
\hline Protein $\%$ & 3.20 & 0.29 & 9 & 3.14 & 0.25 & 8 \\
\hline $\mathrm{pH}$ & 6.76 & 0.07 & 1 & 6.77 & 0.08 & 1 \\
\hline Somatic cell count (ln) & 4.59 & 1.63 & 36 & 5.67 & 1.35 & 24 \\
\hline \multicolumn{7}{|l|}{ Protein composition } \\
\hline Casein \% & 2.49 & 0.25 & 10 & 2.44 & 0.22 & 9 \\
\hline Whey protein \% & 0.53 & 0.08 & 15 & 0.54 & 0.07 & 13 \\
\hline Non-protein nitrogen, $\mathrm{mg} / \mathrm{g}$ & 0.29 & 0.06 & 21 & 0.26 & 0.03 & 12 \\
\hline Casein number & 78 & 2.49 & 3 & 78 & 2.41 & 3 \\
\hline$\alpha_{\mathrm{sl}}$-casein, g/l & 9.47 & 0.98 & 10 & 9.32 & 0.89 & 10 \\
\hline$\alpha_{\mathrm{s} 2}$-casein, g/l & 3.19 & 0.67 & 21 & 2.97 & 0.45 & 15 \\
\hline$\beta$-casein, g/l & 9.40 & 0.99 & 11 & 9.12 & 0.99 & 11 \\
\hline$\kappa$-casein, g/l & 2.87 & 0.41 & 14 & 2.98 & 0.45 & 15 \\
\hline$\alpha$-lactalbumin, $g / l$ & 0.96 & 0.13 & 14 & 0.96 & 0.14 & 15 \\
\hline$\beta$-lactoglobulin, $\mathrm{g} / \mathrm{l}$ & 3.28 & 0.61 & 19 & 3.31 & 0.54 & 16 \\
\hline
\end{tabular}

Finnish Ayrshire; total 59 cows and 174 observations, for $\mathrm{R}$ and $\mathrm{E}_{30}^{\prime} ; 58$ cows and 165 observations and for $\mathrm{K}_{20} ; 53$ cows and 134 observations.

Finnish Friesian; total 55 cows and 155 observations, for $\mathrm{K}_{20} ; 55$ cows and 142 observations. $\overline{\mathrm{X}}=$ mean, $\mathrm{s} . \mathrm{d} .=$ standard deviation, $\mathrm{cv}=$ coefficient of variation $\mathrm{E}_{30}^{\prime}=$ samples with renneting time, used in statistical analyses. 
Ikonen, T. et al. Renneting properties and composition of bovine milk

Gross and protein composition of milk

Even though the renneting properties were somewhat weaker in milk of the FAy, the fat, protein and casein contents and the concentrations of $\alpha_{\mathrm{s} 1^{-}}, \alpha_{\mathrm{s} 2}-$ and $\beta$-caseins were higher than in milk of the FFr (Table 2). The somatic cell count and concentration of $\kappa$-casein were higher in milk of the FFr than in that of the FAy. There were no major differences in concentrations of $\alpha$-lactalbumin and $\beta$-lactoglobulin between the FAy and FFr.

\section{Estimates of genetic variation}

The moderately high heritability estimates for milk renneting properties in both breeds suggested that additive genetic effects made an important contribution to variation in these characteristics (Table 3 ). When $\kappa-\beta-C N$ genotypes and $\beta$ LG genotypes were excluded from Model 1 , the heritability estimates increased by $3-16$ percentage units. A moderate proportion of the additive genetic variation in renneting properties was therefore due to milk protein genotypes. The magnitude of heritability estimates for renneting properties was about the same as that for protein and casein contents and concentrations of $\beta$ - and $\kappa$-caseins in both breeds, and for fat content, and concentrations of $\alpha_{\mathrm{s} 1}{ }^{-}$and $\alpha_{\mathrm{s} 2}$-caseins and $\beta$-LG in the FAy (Table 3). Because the data sets were small, the standard errors of the heritability estimates were high for some traits, but reasonable for renneting properties.

\section{Effects of $\kappa-\beta-\mathrm{CN}$ genotypes}

Of the several traits studied, k-b-CN genotypes had a statistically significant effect on firmness

Table 3. Heritability $\left(\mathrm{h}^{2}\right)$ and repeatability (r) estimates for renneting properties, daily milk yield, and gross and protein composition characteristics of milk from the Finnish Ayrshire and Finnish Friesian.

\begin{tabular}{|c|c|c|c|c|}
\hline & \multicolumn{2}{|c|}{ Finnish Ayrshire } & \multicolumn{2}{|c|}{ Finnish Friesian } \\
\hline & $h^{2} \pm$ s.e. ${ }^{\prime}$ & $\mathrm{r}$ & $h^{2} \pm$ s.e. & $\mathbf{r}$ \\
\hline \multicolumn{5}{|l|}{ Milk renneting } \\
\hline $\mathrm{R}, \min$ & $0.62 \pm 0.14$ & 0.66 & $0.35 \pm 0.21$ & 0.58 \\
\hline $\mathrm{K}_{20}, \min$ & $0.54 \pm 0.13$ & 0.63 & $0.66 \pm 0.10$ & 0.71 \\
\hline $\mathrm{E}_{30}, \mathrm{~mm}$ & $0.41 \pm 0.19$ & 0.64 & $0.57 \pm 0.06$ & 0.57 \\
\hline \multicolumn{5}{|l|}{ Milk yield and composition } \\
\hline Daily milk yield, kg & $0.12 \pm 0.11$ & 0.47 & $0.06 \pm 0.20$ & 0.60 \\
\hline Fat $\%$ & $0.37 \pm 0.07$ & 0.57 & $0.14 \pm 0.15$ & 0.30 \\
\hline Protein $\%$ & $0.34 \pm 0.23$ & 0.59 & $0.19 \pm 0.18$ & 0.57 \\
\hline $\mathrm{pH}$ & $0.08 \pm 0.19$ & 0.46 & $0.05 \pm 0.23$ & 0.43 \\
\hline Somatic cell count $(\ln )$ & $0.18 \pm 0.09$ & 0.57 & $0.38 \pm 0.10$ & 0.41 \\
\hline \multicolumn{5}{|l|}{ Protein composition } \\
\hline Casein \% & $0.50 \pm 0.07$ & 0.52 & $0.20 \pm 0.25$ & 0.56 \\
\hline Whey protein \% & $0.01 \pm 0.04$ & 0.37 & $0.15 \pm 0.18$ & 0.47 \\
\hline Non-protein nitrogen, $\mathrm{mg} / \mathrm{g}$ & $0.00 \pm 0.00$ & 0.42 & $0.02 \pm 0.06$ & 0.17 \\
\hline Casein number & $0.20 \pm 0.10$ & 0.31 & $0.30 \pm 0.35$ & 0.33 \\
\hline$\alpha_{\mathrm{s} 1}$-casein, $g / 1$ & $0.52 \pm 0.07$ & 0.55 & $0.06 \pm 0.13$ & 0.46 \\
\hline$\alpha_{\mathrm{s} 2}$-casein, g/l & $0.31 \pm 0.22$ & 0.46 & $0.00 \pm 0.00$ & 0.40 \\
\hline$\beta$-casein, g/l & $0.40 \pm 0.07$ & 0.41 & $0.33 \pm 0.24$ & 0.51 \\
\hline K-casein, g/l & $0.27 \pm 0.18$ & 0.43 & $0.42 \pm 0.19$ & 0.61 \\
\hline$\alpha$-lactalbumin, g/l & $0.00 \pm 0.00$ & 0.26 & $0.27 \pm 0.08$ & 0.27 \\
\hline$\beta$-lactoglobulin, g/l & $0.35 \pm 0.29$ & 0.48 & $0.21 \pm 0.14$ & 0.54 \\
\hline
\end{tabular}

's.e. = standard error of heritability estimate 
Vol. 6 (1997): 283-294.

of the curd and concentrations of $\mathrm{a}_{\mathrm{s} 2}-$ and $\mathrm{k}$-caseins in the FAy, and on curd firming time, firmness of the curd and k-casein concentration in the FFr. In the FAy, the $A B A_{1} A_{2}, A B A_{1} A_{1}$ and $\mathrm{AAA}_{1} \mathrm{~A}_{2}$ genotypes had a favourable effect on firmness of the curd and k-casein concentration, and the $\mathrm{ABA}_{1} \mathrm{~A}_{1}$ and $\mathrm{AAA}_{1} \mathrm{~A}_{2}$ genotypes on $\mathrm{a}_{\mathrm{s} 2}$ casein concentration (Table 4). In the FFr, the kb- $\mathrm{CN}$ genotypes associated with the most favourable renneting properties and the highest k-casein concentration were $\mathrm{ABA}_{2} \mathrm{~B}, \mathrm{AAA}_{1} \mathrm{~A}_{3}$, $\mathrm{AAA}_{2} \mathrm{~A}_{3}, \mathrm{ABA}_{1} \mathrm{~A}_{2}$ and $\mathrm{ABA}_{2} \mathrm{~A}_{2}$ (Table 5).

\section{Effects of $\beta$-LG genotypes}

The $\beta$-LG genotypes had no statistically significant effect on renneting properties in either breed but they had a strong effect on the protein composition of milk in both breeds (Table 6). Casein content and casein number were highest for the $\beta$-LG BB genotype, and whey protein and $\beta$-lactoglobulin concentrations for the AA genotype.

\section{Associations between renneting properties and composition of milk}

An increase in the $\mathrm{pH}$ of milk had an unfavourable effect on each renneting characteristic in both breeds (Table 7). Some of the milk samples from the FFr had a very high somatic cell count. The somatic cell count did not, however, have a statistically significant effect on renneting properties in either breed. High protein and casein con-

Table 4. Estimates of $\kappa$ - $\beta$-casein genotype effects (with standard errors below the estimates) on firmness of the curd, and $\alpha_{\mathrm{s} 2}$ and $\beta$-casein (cn) concentrations of milk from the Finnish Ayrshire.

\begin{tabular}{|c|c|c|c|c|c|c|c|c|c|c|c|c|}
\hline & $\begin{array}{c}\mathrm{AA} \\
\mathrm{A}_{1} \mathrm{~A}_{1} \\
\mathrm{n}=6\end{array}$ & $\begin{array}{c}\mathrm{AA} \\
\mathrm{A}_{1} \mathrm{~A}_{2} \\
\mathrm{n}=21\end{array}$ & $\begin{array}{c}\mathrm{AA} \\
\mathrm{A}_{2} \mathrm{~A}_{2} \\
\mathrm{n}=40\end{array}$ & $\begin{array}{c}\mathrm{AB} \\
\mathrm{A}_{1} \mathrm{~A}_{1} \\
\mathrm{n}=6\end{array}$ & $\begin{array}{c}\mathrm{AB} \\
\mathrm{A}_{1} \mathrm{~A}_{2} \\
\mathrm{n}=24\end{array}$ & $\begin{array}{c}\mathrm{AB} \\
\mathrm{A}_{2} \mathrm{~A}_{2} \\
\mathrm{n}=6\end{array}$ & $\begin{array}{c}\mathrm{AE} \\
\mathrm{A}_{1} \mathrm{~A}_{1} \\
\mathrm{n}=9\end{array}$ & $\begin{array}{c}\mathrm{AE} \\
\mathrm{A}_{1} \mathrm{~A}_{2} \\
\mathrm{n}=38\end{array}$ & $\begin{array}{c}\mathrm{AE} \\
\mathrm{A}_{2} \mathrm{~A}_{2} \\
\mathrm{n}=6\end{array}$ & $\begin{array}{c}\mathrm{BE} \\
\mathrm{A}_{1} \mathrm{~A}_{1} \\
\mathrm{n}=6\end{array}$ & $\begin{array}{c}E E \\
A_{1} A_{1} \\
n=12\end{array}$ & F-test \\
\hline $\mathrm{E}_{30}, \mathrm{~mm}^{\prime}$ & $\begin{array}{c}-0.2 \\
(6.7)\end{array}$ & $\begin{array}{l}10.4 \\
(4.2)\end{array}$ & 0 & $\begin{array}{l}16.0 \\
(7.2)\end{array}$ & $\begin{array}{l}16.1 \\
(4.3)\end{array}$ & $\begin{array}{c}2.8 \\
(8.8)\end{array}$ & $\begin{array}{l}-4.9 \\
(6.1)\end{array}$ & $\begin{array}{c}4.1 \\
(3.5)\end{array}$ & $\begin{array}{l}-3.6 \\
(7.0)\end{array}$ & $\begin{array}{c}2.8 \\
(6.7)\end{array}$ & $\begin{array}{c}0.0 \\
(5.1)\end{array}$ & $\mathrm{P}=0.005$ \\
\hline$\alpha_{\mathrm{s} 2}-\mathrm{cn}, \mathrm{g} / \mathrm{l}$ & $\begin{array}{c}-0.75 \\
(0.32)\end{array}$ & $\begin{array}{c}0.27 \\
(0.20)\end{array}$ & 0 & $\begin{array}{c}0.42 \\
(0.34)\end{array}$ & $\begin{array}{c}-0.01 \\
(0.20)\end{array}$ & $\begin{array}{c}-0.36 \\
(0.30)\end{array}$ & $\begin{array}{c}-0.86 \\
(0.28)\end{array}$ & $\begin{array}{c}-0.31 \\
(0.17)\end{array}$ & $\begin{array}{c}-0.07 \\
(0.33)\end{array}$ & $\begin{array}{c}-0.78 \\
(0.32)\end{array}$ & $\begin{array}{c}-0.98 \\
(0.24)\end{array}$ & $\mathrm{P}<0.001$ \\
\hline K-cn, g/l & $\begin{array}{c}0.00 \\
(0.21)\end{array}$ & $\begin{array}{c}0.15 \\
(0.13)\end{array}$ & 0 & $\begin{array}{c}0.90 \\
(0.23)\end{array}$ & $\begin{array}{c}0.57 \\
(0.13)\end{array}$ & $\begin{array}{c}0.07 \\
(0.20)\end{array}$ & $\begin{array}{c}0.13 \\
(0.19)\end{array}$ & $\begin{array}{c}0.18 \\
(0.11)\end{array}$ & $\begin{array}{c}0.19 \\
(0.22)\end{array}$ & $\begin{array}{c}0.39 \\
(0.21)\end{array}$ & $\begin{array}{c}0.05 \\
(0.16)\end{array}$ & $\mathrm{P}=0.003$ \\
\hline
\end{tabular}

${ }^{\prime} \mathrm{E}_{30}$, number of observations in genotype classes $=6,21,36,6,24,3,7,38,6,6,12$

Table 5. Estimates of $\kappa-\beta$-casein genotype effects (with standard errors below the estimates) on curd firming time, firmness of the curd and $\kappa$-casein concentration of milk from the Finnish Friesian.

\begin{tabular}{|c|c|c|c|c|c|c|c|c|c|c|}
\hline & $\begin{array}{c}\mathrm{AA} \\
\mathrm{A}_{1} \mathrm{~A}_{2} \\
\mathrm{n}=29\end{array}$ & $\begin{array}{l}\mathrm{AA} \\
\mathrm{A}_{123} \\
\mathrm{n}=4\end{array}$ & $\begin{array}{c}\mathrm{AA} \\
\mathrm{A}_{2} \mathrm{~A}_{2} \\
\mathrm{n}=60\end{array}$ & $\begin{array}{c}\mathrm{AB} \\
\mathrm{A}_{1} \mathrm{~A}_{1} \\
\mathrm{n}=3\end{array}$ & $\begin{array}{c}\mathrm{AB} \\
\mathrm{A}_{1} \mathrm{~A}_{2} \\
\mathrm{n}=23\end{array}$ & $\begin{array}{c}\mathrm{AB} \\
\mathrm{A}_{2} \mathrm{~A}_{2} \\
\mathrm{n}=11\end{array}$ & $\begin{array}{l}\mathrm{AB} \\
\mathrm{A}_{2} \mathrm{~B} \\
\mathrm{n}=5\end{array}$ & $\begin{array}{c}\mathrm{AE} \\
\mathrm{A}_{1} \mathrm{~A}_{1} \\
\mathrm{n}=11\end{array}$ & $\begin{array}{c}\mathrm{AE} \\
\mathrm{A}_{1} \mathrm{~A}_{2} \\
\mathrm{n}=9\end{array}$ & F-test \\
\hline $\mathrm{K}_{20}, \min ^{1}$ & $\begin{array}{c}0.2 \\
(1.3)\end{array}$ & $\begin{array}{l}-4.0 \\
(2.3)\end{array}$ & 0 & $\begin{array}{c}-4.2 \\
(3.2)\end{array}$ & $\begin{array}{c}-4.3 \\
(1.4)\end{array}$ & $\begin{array}{l}-2.3 \\
(1.9)\end{array}$ & $\begin{array}{l}-4.1 \\
(2.3)\end{array}$ & $\begin{array}{c}0.3 \\
(1.8)\end{array}$ & $\begin{array}{c}0.2 \\
(1.9)\end{array}$ & $\mathrm{P}=0.032$ \\
\hline $\mathrm{E}_{30}, \mathrm{~mm}$ & $\begin{array}{c}-3.2 \\
(3.1)\end{array}$ & $\begin{array}{l}14.2 \\
(6.0)\end{array}$ & 0 & $\begin{array}{c}-7.3 \\
(8.1)\end{array}$ & $\begin{array}{c}6.6 \\
(3.5)\end{array}$ & $\begin{array}{c}5.3 \\
(4.8)\end{array}$ & $\begin{array}{l}14.9 \\
(5.9)\end{array}$ & $\begin{array}{l}-2.9 \\
(4.6)\end{array}$ & $\begin{array}{c}-0.4 \\
(4.7)\end{array}$ & $\mathrm{P}=0.012$ \\
\hline א-casein, g/l & $\begin{array}{c}0.04 \\
(0.13)\end{array}$ & $\begin{array}{c}0.58 \\
(0.25)\end{array}$ & 0 & $\begin{array}{c}0.59 \\
(0.34)\end{array}$ & $\begin{array}{c}0.46 \\
(0.15)\end{array}$ & $\begin{array}{c}0.24 \\
(0.20)\end{array}$ & $\begin{array}{c}0.93 \\
(0.25)\end{array}$ & $\begin{array}{c}-0.22 \\
(0.19)\end{array}$ & $\begin{array}{c}-0.08 \\
(0.20)\end{array}$ & $\mathrm{P}<0.001$ \\
\hline
\end{tabular}

${ }^{\prime} \mathrm{K}_{20}$, number of observations in genotype classes $=23,4,53,3,23,11,5,11,9$ 


\section{Ikonen, T. et al. Renneting properties and composition of bovine milk}

Table 6. Estimates of $\beta$-lactoglobulin genotype effects (with standard errors below the estimates) on protein composition of milk from the Finnish Ayrshire and the Finnish Friesian.

\begin{tabular}{|c|c|c|c|c|c|c|c|c|}
\hline & \multicolumn{4}{|c|}{ Finnish Ayrshire } & \multicolumn{4}{|c|}{ Finnish Friesian } \\
\hline & $\underset{n=15}{\mathrm{AA}}$ & $\underset{\mathrm{n}=82}{\mathrm{AB}}$ & $\begin{array}{c}\text { BB } \\
n=77\end{array}$ & F-test & $\underset{\mathrm{n}=20}{\mathrm{AA}}$ & $\underset{\mathrm{n}=97}{\mathrm{AB}}$ & $\begin{array}{c}\text { BB } \\
\mathrm{n}=38\end{array}$ & F-test \\
\hline Casein \% & $\begin{array}{c}-0.23 \\
(0.10)\end{array}$ & 0 & $\begin{array}{c}0.06 \\
(0.06)\end{array}$ & $\mathrm{P}=0.018$ & $\begin{array}{c}-0.11 \\
(0.07)\end{array}$ & 0 & $\begin{array}{c}0.10 \\
(0.05)\end{array}$ & $\mathrm{P}=0.020$ \\
\hline Whey protein \% & $\begin{array}{c}0.03 \\
(0.03)\end{array}$ & 0 & $\begin{array}{c}-0.08 \\
(0.02)\end{array}$ & $\mathrm{P}<0.001$ & $\begin{array}{c}0.08 \\
(0.02)\end{array}$ & 0 & $\begin{array}{c}-0.03 \\
(0.02)\end{array}$ & $\mathrm{P}<0.001$ \\
\hline Casein number & $\begin{array}{c}-2.38 \\
(0.80)\end{array}$ & 0 & $\begin{array}{c}2.52 \\
(0.45)\end{array}$ & $\mathrm{P}<0.001$ & $\begin{array}{c}-2.90 \\
(0.73)\end{array}$ & 0 & $\begin{array}{c}1.68 \\
(0.51)\end{array}$ & $\mathrm{P}<0.001$ \\
\hline$\beta-\lg , g / 1$ & $\begin{array}{c}0.34 \\
(0.19)\end{array}$ & 0 & $\begin{array}{c}-0.70 \\
(0.11)\end{array}$ & $\mathrm{P}<0.001$ & $\begin{array}{c}0.50 \\
(0.15)\end{array}$ & 0 & $\begin{array}{c}-0.55 \\
(0.11)\end{array}$ & $\mathrm{P}<0.001$ \\
\hline
\end{tabular}

$\beta$-lg= $\beta$-lactoglobulin

tents and concentrations of $\alpha_{\mathrm{s} 2}, \beta$ - and $\kappa$-caseins and $\beta$-lactoglobulin had favourable effects on curd firming time and firmness of the curd in both breeds. In addition, a high concentration of $\alpha_{\mathrm{s} 1}$-casein and a high casein number in the FFr and a high concentration of $\alpha$-lactalbumin in the
FAy were favourably associated with milk renneting properties.

The $\kappa-\beta-C N$ genotypes with favourable renneting properties were associated with a high $\kappa$ casein concentration in both breeds and with a high $\alpha_{\mathrm{s} 2}$-casein concentration in the FAy. When

Table 7. Statistically significant regression coefficients of milk renneting properties on daily milk yield, and gross and protein composition characteristics of milk.

\begin{tabular}{|c|c|c|c|c|c|c|}
\hline & \multicolumn{3}{|c|}{ Finnish Ayrshire } & \multicolumn{3}{|c|}{ Finnish Friesian } \\
\hline & $\mathbf{R}$ & $\mathrm{K}_{20}$ & $\mathrm{E}_{30}$ & $\mathrm{R}$ & $\mathbf{K}_{20}$ & $\mathrm{E}_{30}$ \\
\hline Dmy, kg & & & & & & $-0.1^{* *}$ \\
\hline Fat $\%$ & & & & & $-0.6^{*}$ & \\
\hline Protein \% & & & $10.5^{* * *}$ & & $-5.1^{* * *}$ & $17.4^{* * *}$ \\
\hline $\mathrm{pH}$ & $28.4^{* * *}$ & $23.3^{* * *}$ & $-41.7 * *$ & $16.3^{* * *}$ & $10.3^{* *}$ & $-34.5 * * *$ \\
\hline Casein \% & & $-6.4^{*}$ & $11.3^{* * *}$ & & $-5.6^{* * *}$ & $20.6^{* * *}$ \\
\hline Whey protein \% & $12.7^{* * *}$ & & & & & \\
\hline Npn, mg/g & $-13.9^{* *}$ & & & & & \\
\hline Casein number & & & & & & $0.7^{*}$ \\
\hline$\alpha_{\mathrm{s} 1}$-casein, $\mathrm{g} / 1$ & & & & & $-1.0^{* *}$ & $3.9^{* * *}$ \\
\hline$\alpha_{\mathrm{s} 2}$-casein, $\mathrm{g} / \mathrm{l}$ & & $-1.6^{*}$ & $3.6^{*}$ & & $-1.4 * *$ & $4.0^{* *}$ \\
\hline$\beta$-casein, g/l & & & $2.4 * *$ & & $-0.8^{*}$ & $3.0^{* *}$ \\
\hline$\kappa$-casein, g/l & & $-4.1 * * *$ & $8.2 * * *$ & & $-2.6^{*}$ & $10.6^{* * *}$ \\
\hline$\alpha-\mathrm{la}, \mathrm{g} / \mathrm{l}$ & & $-11.3 * * *$ & $14.4 * *$ & & & \\
\hline$\beta$-lg, g/l & & $-3.6 * * *$ & $5.3^{* *}$ & & $-2.1^{* *}$ & $7.0^{* * *}$ \\
\hline
\end{tabular}

Dmy=daily milk yield, $\alpha$-la= $\alpha$-lactalbumin, $\beta$-lg= $\beta$-lactoglobulin

${ }^{*}=\mathrm{P}<0.05,{ }^{* *}=\mathrm{P}<0.01,{ }^{* * *}=\mathrm{P}<0.001$

Npn=Non-protein nitrogen 


\section{AGRICULTURAL AND FOOD SCIENCE IN FINLAND}

Vol. 6 (1997): 283-294.

the $\kappa$-casein or $\alpha_{\mathrm{s} 2}$-casein concentration was included in Model 2, differences in firmness of the curd between $\kappa-\beta-\mathrm{CN}$ genotypes diminished but remained statistically significant ( $\kappa$-casein included: $\mathrm{P}=0.042, \alpha_{\mathrm{s} 2}$-casein included: $\mathrm{P}=0.019$ ) in the FAy. In the FFr, the differences in curd firming time and firmness of the curd between $\kappa-\beta-C N$ genotypes were not statistically significant $(\mathrm{P}>0.10)$ after the $\kappa$-casein concentration had been included in Model 2. Consequently, the favourable effect of certain $\kappa$ - $\beta$ - $C N$ genotypes on curd firming time and firmness of the curd was partly due to the high $\kappa$-casein concentration associated with these genotypes.

\section{Discussion}

\section{Genetic variation of characteristics}

The small data sets in this study were not suitable for estimating variance components and heritability values for the traits studied. Errors in the heritability values assumed can change the significance levels, and possibly lead to bias in estimates of the effects under study (Kennedy et al. 1992). We, however, used variance components estimated from the data, there being no estimates in the literature of the variance components deduced using a repeatability model. The heritability estimates for renneting properties we obtained were about twice as high as those reported by Lindström et al. (1984) for milk renneting time and by Tervala et al. (1985) for each milk renneting trait. However, in Tervala et al. (1985), the standard errors of heritability estimates were very high. In both previous studies, the cows were sampled only once.

\section{Effects of milk protein genotypes}

$\kappa-\beta-\mathrm{CN}$ genotypes with the $\kappa$-casein $\mathrm{B}$ allele had a favourable effect on firmness of the curd in both breeds. There was, however, some varia- tion between the effects of $\kappa$-casein $A B, A A$ and $\mathrm{AE}$ genotypes depending on the effect of $\beta$-casein genotypes or alleles in genotype combinations. In the FAy the $\beta$-casein $A_{1} A_{2}$ genotype, and in the FFr the $\beta$-casein $A_{3}$ and $B$ alleles also had a favourable effect on firmness of the curd.

There was a difference between the effects of the $\kappa$-casein $\mathrm{A}$ and $\mathrm{E}$ alleles on renneting properties. The $\kappa$-casein AA genotype had a favourable effect on renneting properties when in combination with the $\beta$-casein $A_{1} A_{2}$ genotype in the FAy and with $A_{1} A_{3}$ and $A_{2} A_{3}$ genotypes in the FFr. The effect of the $\kappa$-casein $E$ allele was, in contrast, rather unfavourable in each $\kappa-\beta-\mathrm{CN}$ genotype. In the FAy, the $\kappa$-casein $\mathrm{E}$ allele was rather common $(30 \%)$, whereas in the FFr it was rare $(6 \%)$. It is possible that the differences in $\kappa$-casein $\mathrm{E}$ allele frequency and the $\kappa$-casein concentration in milk (Table 2) between the FAy and FFr were partly responsible for the differences in renneting properties between the breeds. A higher frequency of the $\kappa$-casein $E$ allele in the FAy than in the FFr was also observed by Ahlfors (unpublished) in data on about 800 FAy and 100 FFr cows.

The favourable effect of the $\kappa$-casein B allele on milk renneting properties has been reported in several other studies (e.g., El-Negoumy 1972, Schaar 1984, Schaar et al. 1985, Pagnacco and Caroli 1987, Davoli et al. 1990, Oloffs et al. 1992, Van den Berg et al. 1992, Macheboeuf et al.1993, Walsh et al. 1995). Nothing has previously been known, however, of the effect of the $\kappa$-casein $\mathrm{E}$ allele on renneting properties. A favourable effect of the $\beta$-casein B allele on renneting properties similar to that we observed in the FFr was reported by Feagan et al. (1972). According to Marziali and Ng-Kwai-Hang (1986), $\beta$-casein genotypes had no statistically significant effect on renneting properties.

A statistically non-significant effect of $\beta$-LG genotypes on renneting properties such as observed in this study was also reported by Feagan et al. (1972) and Pagnacco and Caroli (1987). According to van den Berg et al. (1992), the $\beta$ LG AA genotype was associated with the shortest renneting and curd firming times. The favour- 


\section{AGRICULTURAL AND FOOD SCIENCE IN FINLAND}

\section{Ikonen, T. et al. Renneting properties and composition of bovine milk}

able effect of the $\beta$-LG BB genotype on casein concentration and casein number, and that of the AA genotype on whey protein and $\beta$-lactoglobulin concentrations were also reported by McLean et al. (1984) and Schaar et al. (1985).

As well as renneting properties, the milk samples were analysed for several gross and protein composition characteristics to establish whether the variation in renneting properties due to milk protein genotypes could be explained by differences in gross or protein composition characteristics between the genotypes. Of the several characteristics, the high $\kappa$-casein concentration in milk explained part of the favourable effect of certain $\kappa-\beta-C N$ genotypes on the renneting properties in both breeds.

We estimated the direct effects of milk protein genotypes on renneting properties by assuming an animal model. We did this because the results for the $\kappa$-casein genotype effects on renneting properties are consistent suggesting that the $\kappa$-casein locus itself affects the renneting properties. There are no previous reports of an animal model being used for estimating the effects of milk protein genotypes on renneting properties. It is, however, possible that there are other quantitative trait loci near the $\kappa$-casein locus that have a considerable effect on renneting properties. Thus, it would be interesting to estimate associations between milk protein geno- types and renneting properties within sires. We could not do so here due to the restricted size of the data sets.

\section{Conclusions}

The $\kappa-\beta-C N$ genotypes $A B A_{1} A_{2}, \mathrm{ABA}_{1} A_{1}$ and $\mathrm{AAA}_{1} \mathrm{~A}_{2}$ in the $\mathrm{FAy}$ and genotypes $\mathrm{ABA}_{2} \mathrm{~B}$, $\mathrm{AAA}_{1} \mathrm{~A}_{3}, \mathrm{AAA}_{2} \mathrm{~A}_{3}, \mathrm{ABA}_{1} \mathrm{~A}_{2}, \mathrm{ABA}_{2} \mathrm{~A}_{2}$ in the FFr were associated with favourable renneting properties, partly due to their association with the high $\kappa$-casein concentration in the milk. The effect of the $\kappa$-casein $E$ allele on renneting properties was unfavourable as compared with that of the $\kappa$-casein B allele, and possibly also with that of the $\kappa$-casein A allele. Results for the effect of the $\kappa$-casein $E$ allele on renneting properties need to be confirmed with a larger data set. The $\beta$-LG genotypes had no effect on renneting properties but they had a strong effect on the protein composition of milk.

Acknowledgements. The authors thank Professor Dr. Georg Erhardt from Justus-Liebig-University, Gießen, Germany for help with the IEF method. The Finnish Animal Breeding Association is thanked for laboratory facilities.

\section{References}

Aaltonen, M.L. \& Antila, V. 1987. Milk renneting properties and the genetic variants of proteins. Milchwissenschaft 42: 490-492.

Davoli, R., Dall'Olio, S. \& Russo, V. 1990. Effect of Kcasein genotype on the coagulation properties of milk. Journal of Animal Breeding and Genetics 107: 458464.

El-Negoumy, A.M. 1972. Effect of polymorphic composition of calcium caseinate sols on their stability to rennin. Journal of Dairy Research 39: 373-379.

Erhardt, G. 1989. א-kaseine in Rindermilch - Nachweis eines weiteren Allels $\left(\kappa-C n^{E}\right)$ in verschiedenen Rassen. Journal of Animal Breeding and Genetics 106: 225-231.
Feagan, J.T., Bailey, L.F., Hehir A.F., McLean D.M. \& Ellis, N.J.S. 1972. Coagulation of milk proteins. 1. Effect of genetic variants of milk proteins on rennet coagulation and heat stability of normal milk. Australian Journal of Dairy Technology, December: 129134.

Groeneveld, E. 1990. PEST user's manual. Institute of Animal Husbandry and Animal Behaviour, Federal Agricultural Research Centre, W 3057 Neustadt 1, Hoeltystr. 10, Germany. 73 p.

- 1993. REML VCE - a multivariate multimodel restricted maximum likelihood (co)variance component estimation package. Institute of Animal Husbandry and Animal Behaviour, Federal Agricultural Research 


\section{AGRICULTURAL AND FOOD SCIENCE IN FINLAND}

Vol. 6 (1997): 283-294.

Centre, W 3057 Neustadt 1, Hoeltystr. 10, Germany. $23 \mathrm{p}$.

Grosclaude, F., Mercier, J.C. \& Ribadeau-Dumas, B. 1973. Genetic aspects of cattle casein research. Netherlands Milk Dairy Journal 27: 328-340.

Kennedy, B.W., Quinton, M. \& Van Arendonk, J.A.M. 1992. Estimation of effects of single genes on quantitative traits. Journal of Animal Science 70: 20002012.

Lindström, U.B., Antila, V. \& Syvăjärvi, J. 1984. A note on some genetic and non-genetic factors affecting clotting time of Ayrshire milk. Acta Agriculturae Scandinavica 34: 349-355.

Macheboeuf, D., Coulon, J.-B. \& D'Hour, P. 1993. Effect of breed, protein genetic variants and feeding on cow's milk coagulation properties. Journal of Dairy Research 60: 43-54.

Marziali, A.S. \& Ng-Kwai-Hang, K.F. 1986. Effects of milk composition and genetic polymorhism on coagulating properties of milk. Journal of Dairy Science 69: 1793-1798.

McLean, D.M., Graham, E.R.B., Ponzoni, R.W. \& McKenzie, H.A. 1984. Effects of milk protein genetic variants on milk yield and composition. Journal of Dairy Research 51: 531- 546.

Ojala, M., Famula, T.R. \& Medrano, J.F. 1997. Effects of milk protein genotypes on the variation for milk production traits of Holstein and Jersey cows in California. Journal of Dairy Science 80: 1776-1785.

Oloffs, K., Schulte-Coerne, H., Pabst, K. \& Gravert, H.O. 1992. Die Bedeutung der Proteinvarianten für genetische Unterschiede in der Käsereitauglichkeit der Milch. Züchtungskunde 64: 20-26.

Pagnacco, G. \& Caroli, A. 1987. Effects of casein and $\beta$ - lactoglobulin genotypes on renneting properties of milks. Journal of Dairy Research 54: 479-485.

Schaar, J. 1984. Effects of k-casein genetic variants and lactation number on the renneting properties of individual milks. Journal of Dairy Research 51: 397-406.

- , Hansson, B. \& Pettersson, H.-E. 1985. Effects of genetic variants of $\kappa$-casein and $\beta$-lactoglobulin on cheesemaking. Journal of Dairy Research 52: 429437.

Syvăoja, E.-L. 1992. Quantitative determination of the main casein components and purification of $\alpha_{\mathrm{s2}}{ }^{-}$and $\kappa$-casein from bovine milk. Milchwissenschaft 47: 563-566.

- \& Korhonen, H. 1994. Determination of colostral immunoglobulins by gel filtration chromatography. International Dairy Federation Bulletin no 9404, Brussels, Begium, 216.

Tervala, H.-L., Antila, V. \& Syväjärvi, J. 1985. Factors affecting the renneting properties of milk. Meijeritieteellinen Aikakauskirja XLIII 1: 16-25.

Threadgill, D.W. \& Womack, J.E. 1990. Genomic analyses of the major bovine milk protein genes. Nucleic Acids Research 18: 6935-6942.

Walsh, C.D., Guinee, T., Harrington, D., Mehra, R., Murphy, J., Connolly, J.F. \& Fitzgerald, R.J. 1995. Cheddar cheesemaking and rennet coagulation characteristics of bovine milks containing $\kappa$-casein AA or BB genetic variants. Milchwissenschaft 50: 492-496.

Van den Berg, G., Escher, J.T.M., de Koning, P.J. \& Bovenhuis, H. 1992. Genetic polymorphism of K-casein and $\beta$-lactoglobulin in relation to milk composition and processing properties. Netherlands Milk and Dairy Journal 46: 145-168. 


\title{
AGRICULTURAL AND FOOD SCIENCE IN FINLAND
}

Ikonen, T. et al. Renneting properties and composition of bovine milk

\section{SELOSTUS}

\section{Kaseiinien yhdistelmägenotyyppien ja $\beta$-laktoglobuliinin genotyyppien vaikutus maidon juoksettumisominaisuuksiin ja koostumukseen}

\author{
Tiina Ikonen, Matti Ojala ja Eeva-Liisa Syväoja \\ Helsingin yliopisto ja Valio Oyj
}

Tutkimuksen tarkoituksena oli selvittää $\kappa$ - ja $\beta$-kaseiinien yhdistelmägenotyyppien ja $\beta$-laktoglobuliinin genotyyppien vaikutusta maidon juoksettumisominaisuuksiin sekä maidon yleis- ja valkuaisainekoostumukseen. Tutkimuksen aineisto koostui Helsingin yliopiston Viikin opetus- ja tutkimustilan 59 ayrshirelehmän 174 maitonäytteestä ja Suitian opetusja tutkimustilan 55 friisiläislehmän 155 maitonäytteestä. Maitonäytteitä kerättiin lehmiltä kolme kertaa lypsykauden aikana; kuukauden, kolmen kuukauden ja viiden kuukauden kuluttua poikimisesta. $\kappa$ - ja $\beta$ kaseiinien yhdistelmägenotyyppien ja $\beta$-laktoglobuliinin genotyyppien vaikutusten selvittämiseen käytettiin eläinmallia, jossa kiinteinä tekijöinä olivat poikimakerta, lypsykauden vaihe, vuodenaika, $\kappa$ - ja $\beta$ kaseiinien yhdistelmägenotyypit ja $\beta$-laktoglobuliinin genotyypit. Satunnaisina tekijöinä mallissa olivat eläimen additiivinen geneettinen vaikutus, eläimen pysyvä ympäristö ja jäännöstekijä.

Kaseiinien kytkeytyneisyyden vuoksi havaintojen lukumäärä eri $\kappa$ - ja $\beta$-kaseiinien yhdistelmägenotyypeissä vaihteli selkeästi. Ayrshirelehmillä maidon juoksettumisominaisuudet olivat parhaimmat $\kappa$ - ja $\beta$ kaseiinien yhdistelmägenotyypeillä $\mathrm{ABA}_{1} \mathrm{~A}_{2}, \mathrm{ABA}_{1} \mathrm{~A}_{1}$ ja $A A_{1} A_{2}$ ja friisiläislehmillä yhdistelmägenotyypeillä $A B A_{2} B, A A A_{1} A_{3}, A A A_{2} A_{3}, A B A_{1} A_{2}$ ja $\mathrm{ABA}_{2} \mathrm{~A}_{2} \cdot \kappa$-kaseiinin $\mathrm{E}$-alleeli vaikutti epäedullisesti maidon juoksettumisominaisuuksiin B-alleeliin ja luultavasti myös A-alleeliin verrattuna. Juoksettumisominaisuuksiltaan parhaimmilla yhdistelmägenotyypeillä oli yhteys maidon korkeaan $\kappa$-kaseiinipitoisuuteen kummallakin rodulla. Maidon $\kappa$-kaseiinipitoisuus vaikutti edullisesti maidon kiinteytymisaikaan sekä juoksettuman kiinteyteen kummallakin rodulla. Osa yhdistelmägenotyyppien vaikutuksesta maidon juoksettumisominaisuuksiin johtui siten niiden vaikutuksesta maidon kaseiinikoostumukseen. $\beta$-laktoglobuliinin genotyypeillä ei ollut vaikutusta maidon juoksettumisominaisuuksiin. $\beta$ - laktoglobuliinin genotyypit vaikuttivat kuitenkin maidon valkuaisainekoostumukseen. $\beta$-laktoglobuliinin AA genotyyppi oli yhteydessä maidon korkeaan heraproteini- ja $\beta$-laktoglobuliinipitoisuuteen ja BB genotyyppi korkeaan kaseiinipitoisuuteen sekä kaseiinilukuun. 